\title{
Tourism and COVID-19: The Show Must Go On
}

\author{
Teresa Borges-Tiago ${ }^{1, * \mathbb{D}}$, Sandra Silva ${ }^{2}$, Sónia Avelar ${ }^{1}$, João Pedro Couto ${ }^{1}$, Luíz Mendes-Filho ${ }^{3}$ \\ and Flávio Tiago ${ }^{1} \mathbb{D}$
}

1 Department of Business, University of the Azores, 9500 Ponta Delgada, Portugal; sonia.mm.avelar@uac.pt (S.A.); joao.pa.couto@uac.pt (J.P.C.); flavio.gb.tiago@uac.pt (F.T.)

2 Unidade de Saúde de Ilha de São Miguel, 9500 Ponta Delgada, Portugal; sandra.cs.silva@azores.gov.pt

3 Department of Tourism, Federal University of Rio Grande do Norte, Natal 59072-970, Brazil; luiz.mendes@ufrn.br

* Correspondence: maria.tp.tiago@uac.pt

Citation: Borges-Tiago, T.; Silva, S.; Avelar, S.; Couto, J.P.; Mendes-Filho, L.; Tiago, F. Tourism and COVID-19: The Show Must Go On. Sustainability 2021, 13, 12471. https://doi.org/ $10.3390 /$ su132212471

Academic Editor: Michael Tarrant

Received: 3 October 2021

Accepted: 9 November 2021

Published: 11 November 2021

Publisher's Note: MDPI stays neutral with regard to jurisdictional claims in published maps and institutional affiliations.

Copyright: (c) 2021 by the authors. Licensee MDPI, Basel, Switzerland. This article is an open access article distributed under the terms and conditions of the Creative Commons Attribution (CC BY) license (https:// creativecommons.org/licenses/by/ $4.0 /)$.

\begin{abstract}
Tourism and hospitality actors face an unprecedented challenge in reigniting these industries through digital communication. All past knowledge regarding tourist behavior and preferences has been rendered irrelevant since the outbreak of the COVID-19 pandemic and its resulting enforced changes. Several reports have pointed to the existence of a travel sentiment that may be actionable by communication. This work attempts to reveal some of the elements that may compose this travel sentiment. To pursue this aim, an online pilot survey was conducted among those who were regular travelers before the COVID-19 outbreak. The data was used to validate the conceptual model through a partial least squares structural equation model estimation. The findings revealed that travel constraints are the most influential dimension, along with social media and technology usage, in affecting tourist behavior. Thus, in their communication strategy, tourism and hospitality players should reinforce the health- and hygiene-related measures taken, while simultaneously promoting the trustworthiness of the shared information.
\end{abstract}

Keywords: COVID-19; destination; tourism motivation; online communication; healthcare policy

\section{Introduction}

Tourism was one of the industries most affected by the COVID-19 pandemic [1]. Yet, during the lockdown, governments, healthcare managers, and epidemiologists, as well as entrepreneurs and individuals worldwide, planned and dreamed of their next steps, reflecting their resilience and desire to return to their previous lives [2,3].

The reopening of tourism activities has differed worldwide, reflecting each government's concern about ensuring public health and safety. It has also highlighted the capabilities of digital communication related to health and safe destinations [4]. Hu et al. [5] noted that social media has become a relevant information source for consumers, specifically tourists searching for their destinations' health guidelines and restrictions. However, not all online virtual communities provide safe access to reliable information [6], highlighting the need to promote information-quality assessment models.

In the current scenario, as an increasing number of people begin to travel again, it is important to understand that, as pointed out by several authors, consumers' behaviors have changed as a result of the COVID-19 pandemic in several ways [7-9]. Some of these changes remain unexplored and need evidence to support their relevance [10]; outside academia, new concepts are being presented and adopted to guide digital communication [11]. Moreover, the reflections and research conducted within academia and those performed by consultancy firms use different designations for similar phenomena. Thus, instead of helping tourism and hospitality firms to improve their knowledge and capabilities of designing target digital communication, this has led them to produce less useful and undifferentiated communication strategies. One of these concepts is that of travel sentiment, which reflects the tourist's willingness to travel and is reported in non-academic 
reports as the composite of travel intentions, trip planning, and travel concerns. Unfortunately, within academia, the studies related to tourists' sentiment regarding travel focus on airline traveling [12], leaving this travel sentiment trilogy-based model untested.

Thus, this study attempts to validate the travel sentiment model by combining the existing literature with evidence from a pilot study. The literature review impelled us to add two additional constructs to the model, related to technology and social media usage.

Thus, the adopted model describes certain critical elements to consider when promoting an efficient online communication strategy, such as revisiting travel motivations, sources of information both pre- and during travel, and changing preferences regarding human-technology interactions because of health protection measures. An online survey was conducted based on these elements, and the initial findings retrieved from partial least squares structural equation model estimation are described in the following sections.

The framework adopted in this study provides marketers and managers with specific knowledge to support more efficient social media communication. In addition, it highlights the fact that these digital communication strategies need to consider the modifications to tourist behavior that have occurred in the post-COVID-19 era, mainly their preference for traveling within their own country and for destinations promoted as "safer" regarding COVID-19.

\section{Background}

The COVID-19 pandemic has affected all sectors of activity on a global scale. The tourism industry is no exception, with air, sea, and land connections being disallowed at different times for leisure travel. Consequently, tourists have not been able to leave their homes and enjoy their time away as usual; on the contrary, they have had to stay indoors and adapt to a new, "forced" reality.

This reality of postponing travel plans has challenged tourism and hospitality firms to revisit a combination of dimensions that may influence the travelers' decision processes [13] in relation to producing engaging online communication to revitalize tourism.

\subsection{Tourism and the COVID-19 Pandemic}

Sigala [14] believes that "COVID-19 tourism research should also challenge our growth paradigms and assumptions that have led to the current situation and enable us to reimagine and re-set tourism" (p. 313). Thus, this work revisits the connection between tourism and technology, specifically that of social media and its implications in information-searching patterns [15-17], and adds the destination health conditions that seem to be essential for understanding these travel behaviors and motivations.

As Abdullah et al. [15] recalled, over the past two years, countries have implemented distinctive degrees of restrictions to prevent and constrain the spread of the virus. Given the public health emergency triggered by the proliferation of COVID-19, it was urgently necessary to define and implement feasible measures to contain the spread of SARSCoV-2. Initially, social distancing and confinement strategies were adopted to reduce the transmissibility of the virus, before pressure on the world's economic, social, and health systems was gradually alleviated. However, with this first line of intervention, a new phase was initiated. Health organizations began to project a conduct transition, building a public health strategy as an alternative to confinement. Considering the complexity and the need to prolong this process, this new phase was a huge challenge, but it opened the doors to restarting tourism at a national/domestic level.

During this period, many countries organized classification systems that established alert levels according to the epidemiological situation, for which they defined a set of measures adjusted to each level. The introduction, adaptation, or even suspension of these criteria was based on developments in scientific knowledge and the pandemic, the transmissibility index of the SARS-CoV-2 virus, access conditions and the responsiveness/adaptation of health systems, local contexts, and the implications of measures for the wellbeing of the community and people. However, this framework of the different levels 
lacked a benchmark of criteria that would support a transition between them. Therefore, it was necessary to share scientific evidence that supported the choice of measures implemented and the prior involvement of communities in the planning and management of these measures, to increase the degree of trust and adherence. As Gössling et al. [18] noted, this health condition affected tourism in many ways, including changing mobility patterns and travel motivations, thereby giving domestic tourism a new role in post-COVID-19 economic recovery.

Throughout the world, several measures were implemented related to personal protection (hand hygiene, respiratory labels, mask use, physical distancing, avoidance of crowded environments), the environment (cleaning, disinfection, ventilation), containment (isolation, quarantine, passive surveillance of positive cases), the empowerment of communities (involvement of the media as a determining partner in the sharing of credible and timely information, promotion of health literacy through events in a webinar format), and epidemiological surveillance (mass testing, testing suspected cases, tracing contacts, active surveillance of identified cases, determining the origin of/locating active transmissions, classifying the type of transmission, conducting a serological assessment of the incidence of infection, and calculating the total number of identified cases, cases in the last $24 \mathrm{~h}$, and recovered patients). This complex system was necessary to overcome the propagation of the virus and diminish uncertainty, to allow the restarting of economies and, more specifically, tourism [16-18]. As Abdullah et al. [15] noted, all these changes point to a significant modification in the primary purpose of traveling. Moreover, Falahuddin et al. [19] posit that global health policies and those measures taken to contain COVID-19 have altered risk perception, especially in those that concern international traveling and, consequently, travel motivations and intention.

\subsection{Travel Motivations and Travel Sentiment}

Although this health crisis may have profoundly impacted tourists' views and feelings [20], the importance of traveling remains strong, even if some changes are needed. These changes are reflected in how-and more importantly, why-people travel in an uncertain post-pandemic environment [19]. In general, travel behavior and tourism motivation focus on the tourists and their decision-making process when booking a holiday. By examining consumer behavior, one can acquire information on the different steps a tourist takes before booking a trip and how their background influences their decisionmaking [21,22]. Tourism motivation reflects tourists' behaviors, preferred activities, and reasons for travel [22].

Tourism motivation is a state of need or a condition that causes the tourist to take a holiday that is likely to bring satisfaction by addressing the said state of need or condition. Tourism motivation elucidates why people want to travel, the destination-choice motive, and the specific activities engaged in while on holiday [21].

Motivations to travel have long been a research subject of interest. Several psychological and sociological theories of motivation have provided essential data about the reasons why people travel [22].

The adverse impact of the pandemic might have affected a change in people's motives to travel [23], as external events or crises frequently change travel motivations [24]. Aebli, Volgger, and Taplin [24] found that hygiene factors characterized tourists' travel motivation during the COVID-19 crisis; in fact, tourists consider the potential risks of traveling in their decision-making, along with their travel motives [19]. Aebli, Volgger, and Taplin [24] adopted Herzberg's theory of motivation as a framework for considering the benefits and risks of travel. What tourists equate as healthy and safe is now of primary concern; their willingness to travel is modeled by their risk awareness [19]. When considering the different perspectives and their evolution over time, several travel motives are linked to noveltyseeking, escape/relaxation, self-development, and relationships. Camilleri [25] regrouped these motivations into four dimensions: physical, cultural, personal, and prestige and status. More recently, as Miao et al. [17] found, social distancing and voluntary de-crowding 
behavior could also be considered to influence traveling. Abdullah et al. [15] added perceived risk and fear of infection to this list.

As previously noted, evidence shows that travel motivation influences people's visit intention. The same is true for the perceived risks and travel constraints that influence travel intention [26]. Godovykh et al. [27] explored the perceived risks after the pandemic. These authors acknowledged risk perceptions as a multi-dimensional construct encompassing financial, political, social, psychological, physical, and health risks. Khan et al. [26] found that not all perceived risks have the same influence: perceived travel risks, performance, and time risks had negative effects, while physical, financial, and socio-psychological risks have a neutral impact. According to Godovykh et al. [27], health risk perceptions remain less widely explored. According to these authors, health risk perception underlies "people's knowledge and understanding of the disease, personal experience and trust" (p. 740). Nonetheless, considering the findings of Yu et al. [20], it is unsurprising to find that tourists use social media as a source of information related to COVID-19 and as a social support network during uncertain times. Moreover, social media usage will positively affect travel intention, travel concerns, and trip planning, since traveler information-seeking behavior can influence the overall travel decision-making process.

Travel constraints have been widely researched in terms of the tourist field [28]. However, the pandemic scenario has enhanced some of the dimensions of this equation that need to be revisited. Among travel constraints, interpersonal and intrapersonal risks and limitations were considered to be negatively related to visiting intention [26]. Wilson and Chen [29] added the travel elements and safety and health policies and regulations at the origin and destination countries. Sánchez-Cañizares et al. [30] also considered the effect of financial risks perception as a concern when traveling. To these authors, the financial risks were related to unexpected expenses due to this new reality. However, financial risks can also occur due to cancellation or rescheduling needs [31].

In the early pandemic situation, potential tourists tended to postpone their traveling plans. Afterward, the trip planning assumed a new configuration, considering the travelers' perceived risks and new traveling patterns [15,19,32].

Apart from academic studies, several surveys have been conducted worldwide to determine the reasons influencing the choice of a destination, accommodation, transportation, and travel intention origin of the so-called travel sentiment. Figure 1 presents the evolution of travel sentiment since early 2020 .

50

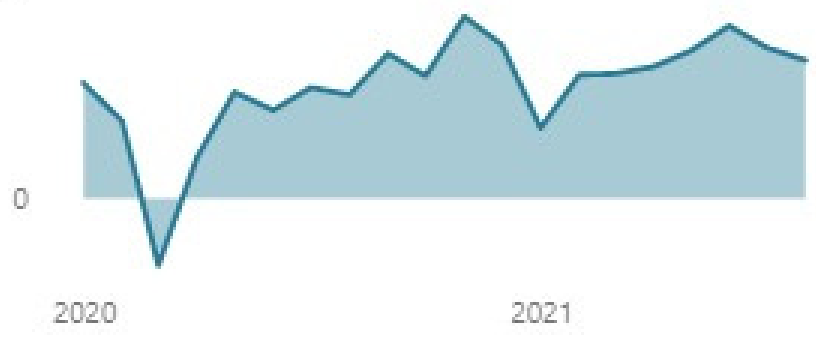

Figure 1. Travel sentiment evolution. Source: UNWTO Tourism Recovery Tracker, retrieved from https:/ / www.unwto.org/unwto-tourism-recovery-tracker accessed on 23 October 2021.

This concept of travel sentiment integrates three dimensions that are already considered in the literature but not always assessed together: travel intentions, trip planning, and travel concerns [32-34] (see Figure 2). Moreover, although firms acknowledge the concept of travel sentiment, it has not been tested with other variables known to affect tourist behavior, which is a gap that the present study aims to address. 


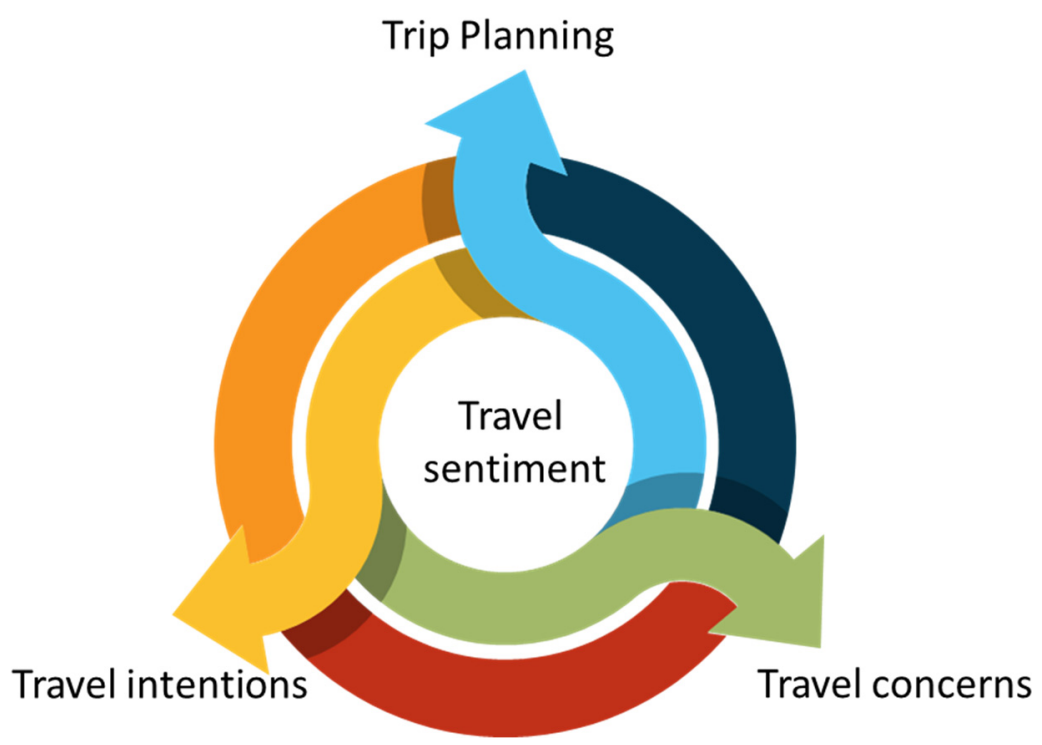

Figure 2. Travel sentiment construct.

Many studies have been conducted in the tourism and hospitality field related to travel sentiment analysis [35]. Nonetheless, these studies focus on assessing the feelings expressed by tourists on different platforms, using opinion-mining and sentiment analysis techniques. Therefore, although semantically similar, the travel sentiment considered in this research does not correlate with the feelings expressed in reviews. Instead, it elucidates the actual willingness to travel. Unfortunately, as far as the authors know, no investigation has been produced to validate the present travel sentiment model.

\subsection{Tourism, Technology, and Digital Communication}

The tourism industry has been dependent on technology for various purposes, ranging from digital communication to service innovation. The latter has evolved from in-room entertainment to interactive systems (e.g., self-check-in kiosks) [36]. This shows that the industry is constantly exploring new technological innovations to improve its offers (e.g., provider sites and mobile phone applications) [37]. Much of the production and delivery of tourist goods and services is now in the process of being fully automated [38] and is generating positive responses from tourists [39].

To Sigala [14], Tourism 4.0 can be referred to as a new ecosystem of tourist value, built on a paradigm of highly technology-based service production and supported by the common principles of Industry 4.0. This ecosystem relies on several components, such as interoperability, virtualization, decentralization, real-time data collection and analysis capability, service guidance, and modularity [40], where technology is used to improve tourist-firm interactions and experiences [41,42].

Various new technologies have also been applied in tourism, such as the Internet of Things (IoT), big data analytics, artificial intelligence (AI), blockchain, location-based services or virtual systems, and augmented reality [40,42]. Several new technologies to support Tourism 4.0 already exist, such as autonomous agents and things (e.g., intelligent voice assistants or autonomous cars) [43] and anthropomorphic service robots [38,44].

Since the introduction of the Internet to the business arena, information technology (IT) has been an important facilitator, catalyst, and-in some cases-disruptor for travel and tourism $[42,45,46]$.

This is particularly true in today's world, as IT has been introduced into all travel and tourism processes, every interested party in tourism, and every subdomain of the industry [42,45-47].

In addition, mobile usage has dramatically changed tourism behaviors and business processes in hospitality and tourism [48,49]. Law et al. [50] believe that the widespread 
adoption of mobile technologies by consumers for travel-related purposes has resulted in the development of relevant mobile information services, including mobile electronic tour guides or application-based mobile tourism guides, mobile payment using near-field communication technologies, and global positioning systems to conduct location-based marketing.

The current COVID-19 pandemic has accelerated technological advancements [51]. Some tourism organizations have switched to virtual solutions to satisfy people's desire for travel, such as virtual tours. However, the long-term effects of recent advances in visual and immersive technologies remain unknown [52].

Although physical tourism has almost come to a halt, past and potential tourists have been busy remembering past trips on social media or dreaming of future vacations, browsing through destination websites. Museums have opened virtual doors to their exhibits, social media travel influencers continue to produce content, and tour providers use a series of online channels to maintain their relationships with customers [51].

The industry has never before experienced such unprecedented, global restrictions, to the point where tourism companies are pressured to find a way to innovate for survival. It is, therefore, crucial to deliberate on how tourism can continue to remain resilient, sustainable, and eventually thrive in a post-pandemic world $[3,53]$.

One possibility is the intensification of extended reality in tourism, using immersive technology. Extended reality is an umbrella term for an entire spectrum of immersive technology-assisted realities (e.g., virtual reality (VR), augmented reality (AR) [54], augmented virtuality $(\mathrm{AV})$, mixed realities (MR), and future realities [53].

The reopening of tourist destinations and the economy implies using new technologies to ensure health and safety (e.g., mobility tracking applications, robotic contactless services, digital health passports and identity controls, social distancing technologies, and crowding management). On the other hand, there is a need to collect and analyze personal data for rapid decision-making (e.g., big data for quick and real-time decision-making). Other technologies involve robots that provide materials, disinfect and sterilize public spaces, detect or measure body temperature, and provide safety [14].

A report from the World Travel and Tourism Council highlighted contactless technologies as a prerequisite for a safe and seamless travel experience [55]. In addition, post-COVID-19, technology will have to accommodate changes in not only consumer behavior (e.g., risk perceptions, last-minute bookings, and early bookings in new contexts such as museums, highlighting the need for highly customized packages) but also the inter-action modus (e.g., from physical touch to voice input or automated detection) [51].

However, not everyone has access to technology and can afford to travel in the future, as rising operating costs (hygiene and technology) and transport oligopolies can increase tourism costs. Similarly, digital inequalities in the tourism business increase economic disparities in the competitive tourism landscape (e.g., larger companies/destinations characterized by increased cash liquidity, know-how, technological readiness, and resilience are less vulnerable to COVID-19, and are likely to survive and thrive after COVID-19) [13]. At this point, the value of technology usage, such as automation technologies, robots, and virtual/augmented reality, is questionable as a driver of travel willingness. Moreover, technology can be explored as an automation tool and as a communication and interaction tool.

Although the use of technology has increased during the pandemic, its adoption in tourism is not entirely new (see Figure 3). Thus, as these technologies proliferate [47], revealing who, when, what, and why they impact, it is important to note the different contexts in the tourism and hospitality industry within which they are used [56]. 


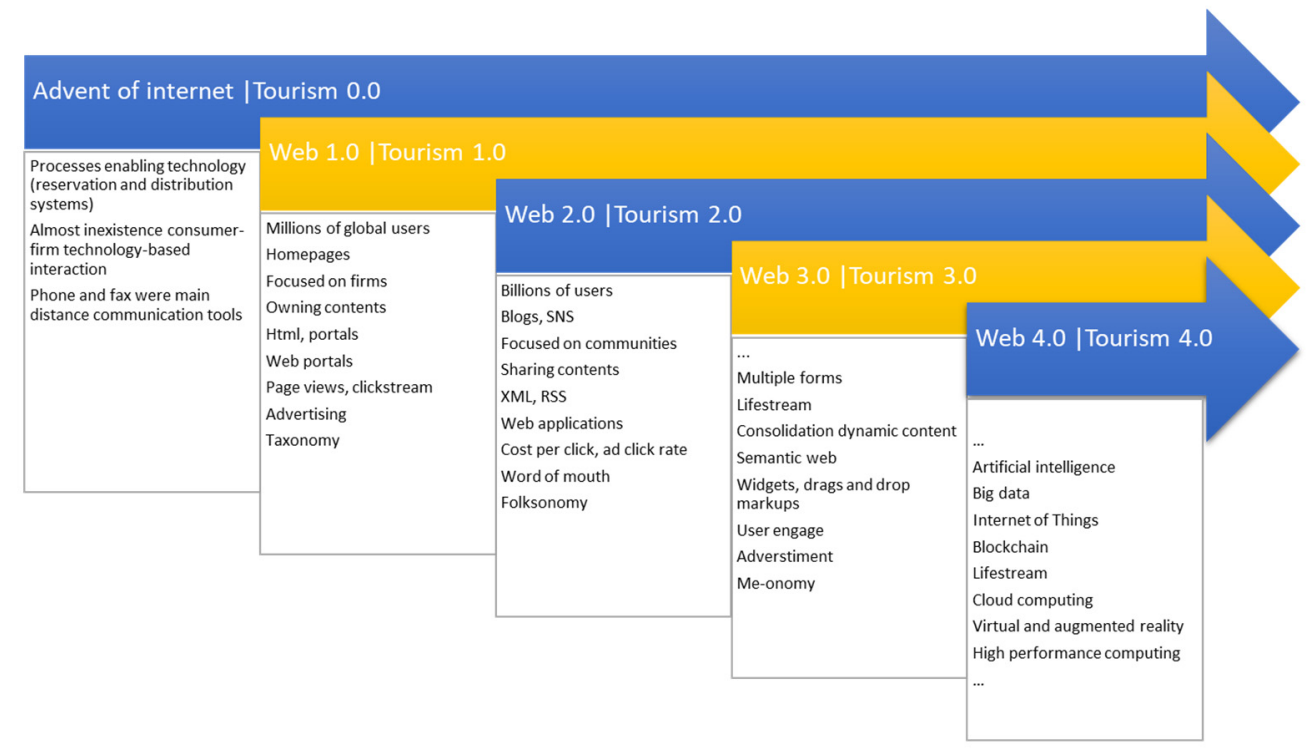

Figure 3. Digital empowerment in tourism. Source: adapted from Tiago et el. [57].

The most substantial changes occurred after Web 2.0, when users were empowered with a set of content-creation tools that shifted the communication paradigm [58,59]. During the last two decades, they have become active online searchers and creators of all kinds of information. As noted by Fotis et al. [60], the use of social media reflects and influences tourists' perceptions, attitudes, behaviors, and shopping requirements. Moreover, social media provides an ecosystem in which information flows faster and is amplified so that organizations can be noticed via small investments and in short time periods. As social media grows, communication strategies are increasingly tailored to target digital users on different platforms [61]. Thus, developing effective and engaging communication on social media is an ongoing challenge for tourism and hospitality firms [59,62], one that relies on identifying tourist behavior, co-creating experiences, and transforming big data into actual knowledge [63].

In general, since the COVID-19 pandemic, numerous behavioral changes among consumers, related to the use of technology and social media, have been noted $[8,9]$. Nonetheless, not all consumers present the same behavioral changes, and social media alters how the Internet is used as both a communication channel and information repository [64]. For example, before 2020, people used social media to share their travel experiences under a broad set of motivations and tended to rely on social media as a credible information source [65]. However, in this new scenario, social media has become a source of health information that flourishes without any supervision, where credible information is presented side by side with fake news, affecting consumer trust in the available information [66].

Hysa et al. [64] identified four everyday activities conducted by tourists over social media that are not influenced by age cohorts:

1. Planning a trip;

2. Acknowledging the destination's cultural and natural heritage;

3. Finding more problematic activities or issues related to the trip; and

4. Revealing the roots of the establishment of community relationships.

However, several differences were compiled within these four blocks, since not all tourists value the same peer opinions and trust the information available online [67].

Considering the relevance of social media to tourism as an information source that affects travel intention and planning a trip, evidence reveals that social media also becomes a space to dream about future trips [66] and pursue new innovative service models $[16,55,64]$.

Searching for and sharing information online, especially on social media, are the cornerstones of the present and future digital communication models [11]. In the past, digital communication assumed the format of one-way communication; however, with Web 
2.0, it shifted to an interaction paradigm [58] that benefits both firms and consumers [44,57]. Thus, digital communication can assume four different configurations that need to be considered simultaneously (see Figure 4).

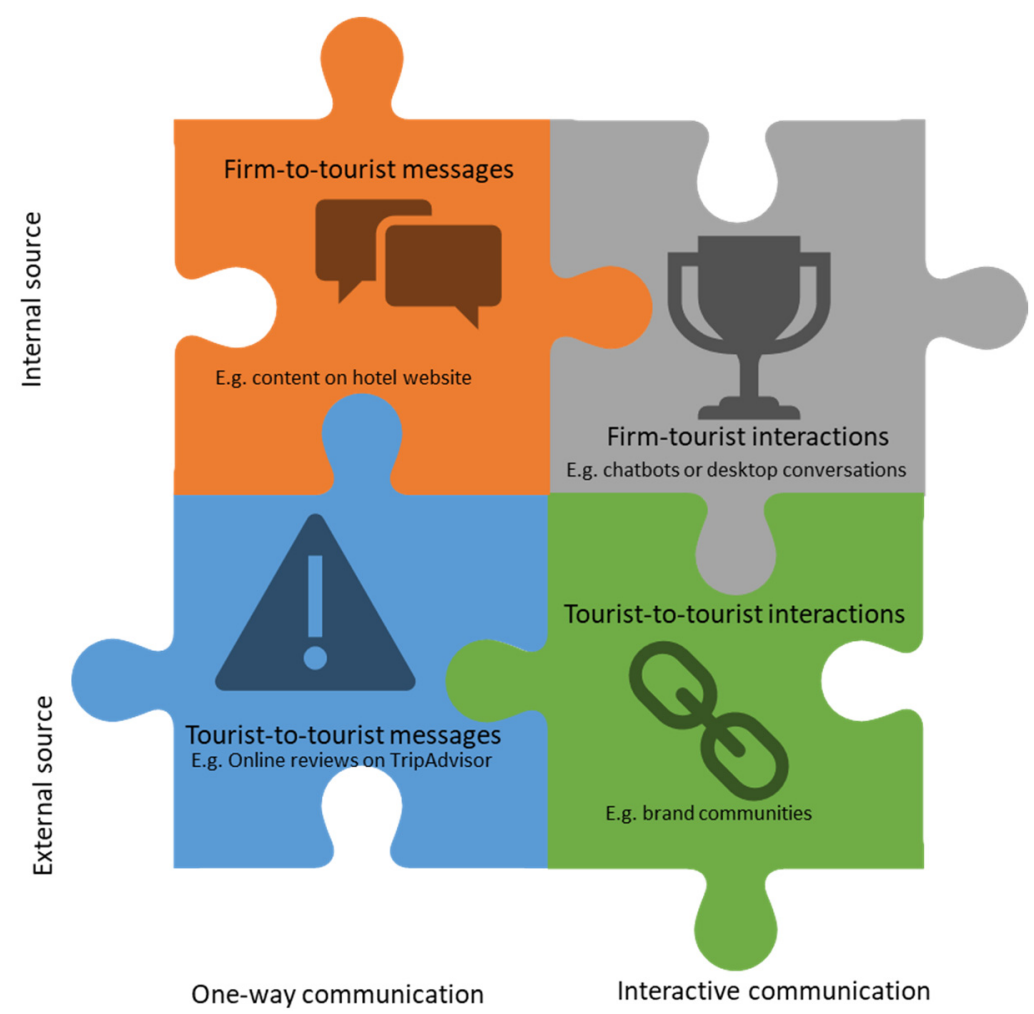

Figure 4. Digital communication dynamics. Source: Adapted from Grewal et al. [11].

Digital communication evolves into new and more complex branches $[7,61,68]$ to meet the needs of customers [11], who inevitably grow and change over time, due to the accumulation of experiences and interactions not only as tourists but also as people $[8,17]$.

The roles of social media and digital communication will increase in the near future and impact tourism and hospitality firms [59], allowing them to reach current and potential tourists [64]. Moreover, this will enable firms to reach out to those who are interested and reignite their wish to travel with trustworthy messages [7].

Thus, understanding and predicting travel behaviors are vital to sustain a target and ensure successful digital communication [68], in order to communicate uniquely with each tourist, considering his or her travel health concerns and sentiments. Considering this new scenario, in which tourist behavior is like an unopened gift box that needs to be carefully analyzed from different angles to ensure that the digital communication is meaningful and effective, this research attempts to answer the following three questions:

1. RQ 1. Does social media usage positively impact travel intention and trip planning?

2. $R Q$ 2. Are there positive spillovers from the adoption of technology by the destination in terms of travel intention and travel concerns?

3. RQ 3. How much do travel intentions, trip planning, and travel concerns influence tourists' willingness to travel, coined from travel sentiment, post-COVID-19?

\section{Method}

This study seeks to reveal some of the behavioral changes among potential tourists caused by the pandemic, which need to be acknowledged by tourism and hospitality firms as well as destination marketing organizations (DMOs), in their digital communications to reignite tourism activity. 
The tourism and hospitality industries are increasingly being shaped by technology. New applications and contactless solutions are now offered to minimize the health risk of contact. Robots or other technological applications are cleaning, ensuring the hygiene of spaces. Social networks are consolidating their role as an information repository and communication channel, while also reshaping the business value chain. Evidence found in the existing literature supports the idea that technology usage by firms in their daily operations is perceived as having a positive impact on travel intentions, concerns, and trip planning since these can minimize some of the transmission risks and constraints associated with COVID-19. The same positive result is found related to the usage of social media by tourists.

A concept that has been used outside the academy to assess a tourist's willingness to travel is the idea of travel sentiment (e.g., the UNWTO Tourism Recovery Tracker, available at https:/ / www.unwto.org/unwto-tourism-recovery-tracker, accessed on 23 October 2021). The travel sentiment is a composite that derives from travel intentions, travel concerns, and trip planning. This work attempts to find evidence that these dimensions can equally influence travel sentiment, or in other words, tourists' willingness to travel. Thus, a conceptual model was composed, reflecting these assumptions, since they can be explored when crafting a digital communication strategy. Besides establishing the travel sentiment, the model also assessed the impact of social media and technology on travel intentions, travel concerns, and trip planning (see Figure 5).

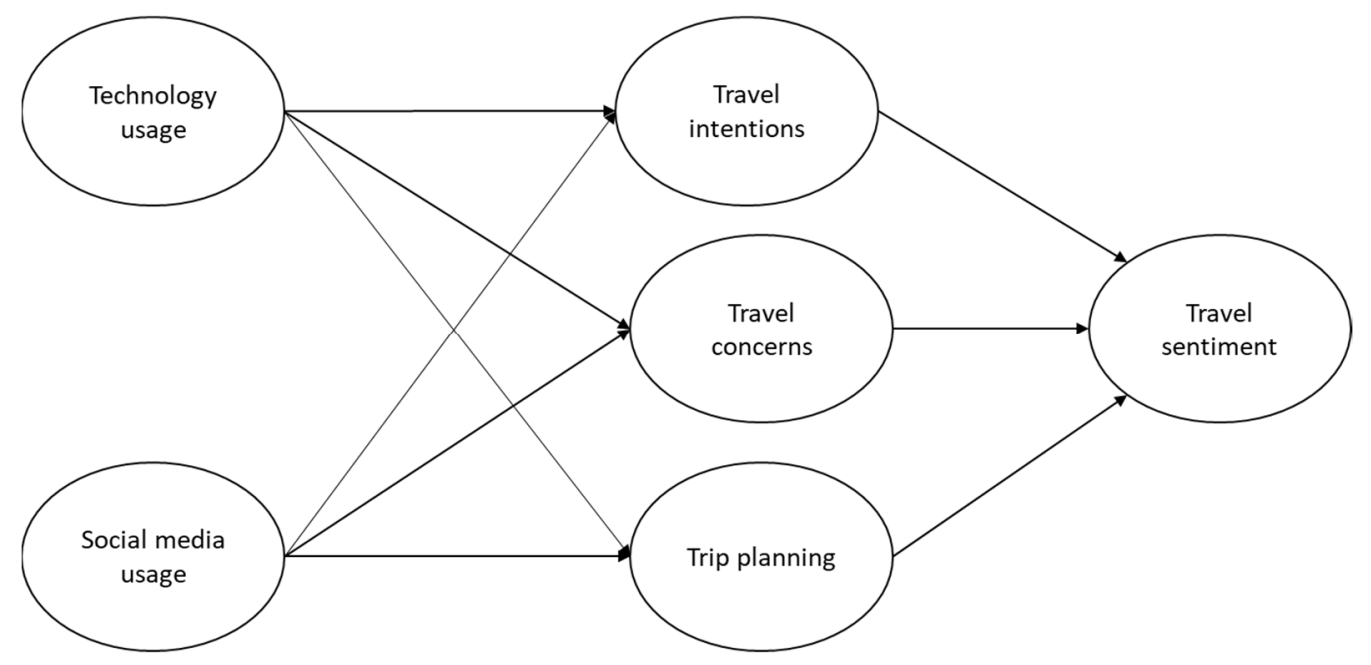

Figure 5. Conceptual model.

In order to validate the proposed conceptual model, a partial least squares method of structural equation modeling (PLS-SEM) was used, assisted by SmartPLS 3.3.3 software. The choice of using a SEM-PLS model considered two main reasons:

1. The research objective is to conduct exploratory research for theory development, considering less explored approaches;

2. The pilot-sample size is small [69].

In addition, this multivariate analysis technique has been adopted in prior research into consumer behavior related to the tourism and hospitality field [70].

\section{Survey Design and General Profile}

As this study is exploratory, a travel behavior pilot survey focused on the new dynamics of travel behavior and multiple aspects of tourists' travel habits, attitudes, and preferences. The questionnaire was designed using LimeSurvey tools. It was prepared in English and distributed through social media, adopting a snowball sampling method, in the first week of September 2020. As part of the data collection for the pilot, a screening question was included for respondents to report the main reasons for not going on holiday 
next year. The initial online sample had 96 valid participants, whose responses were used to validate the established conceptual model.

The questionnaire consisted of four sections:

1. Socio-demographic characteristics;

2. Traveling patterns before and post COVID-19;

3. Reasons and concerns for going on holiday; and

4. Technology and information sources.

Figure 6 summarizes the frequency distributions of our collected data in terms of basic socio-demographics, including gender, marital status, and education.

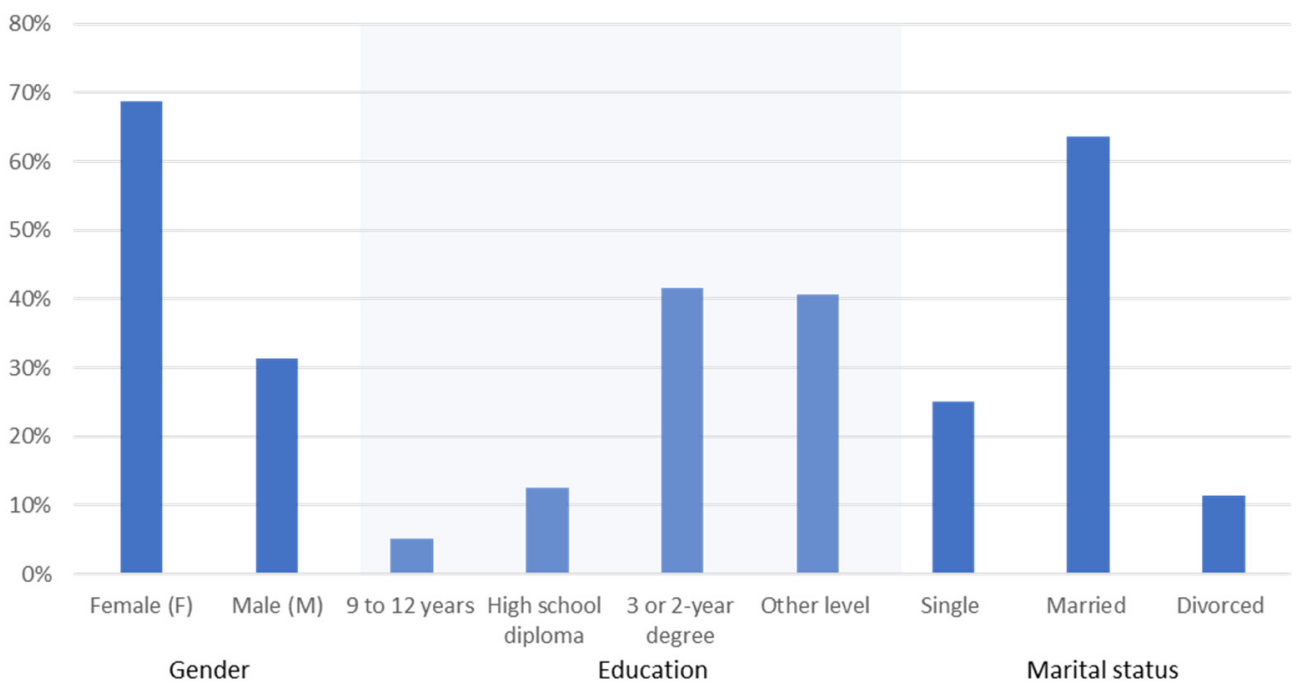

Figure 6. Profiles of the participants.

The average age of the participants was 44 years; the youngest and oldest participants were 22 and 73 years old, respectively. Of all participants, $23.96 \%$ acknowledged traveling once a year before COVID-19, while 33.33\% traveled more than twice a year (see Figure 7). In addition, $51.04 \%$ of the participants made these trips with their spouse or partner.

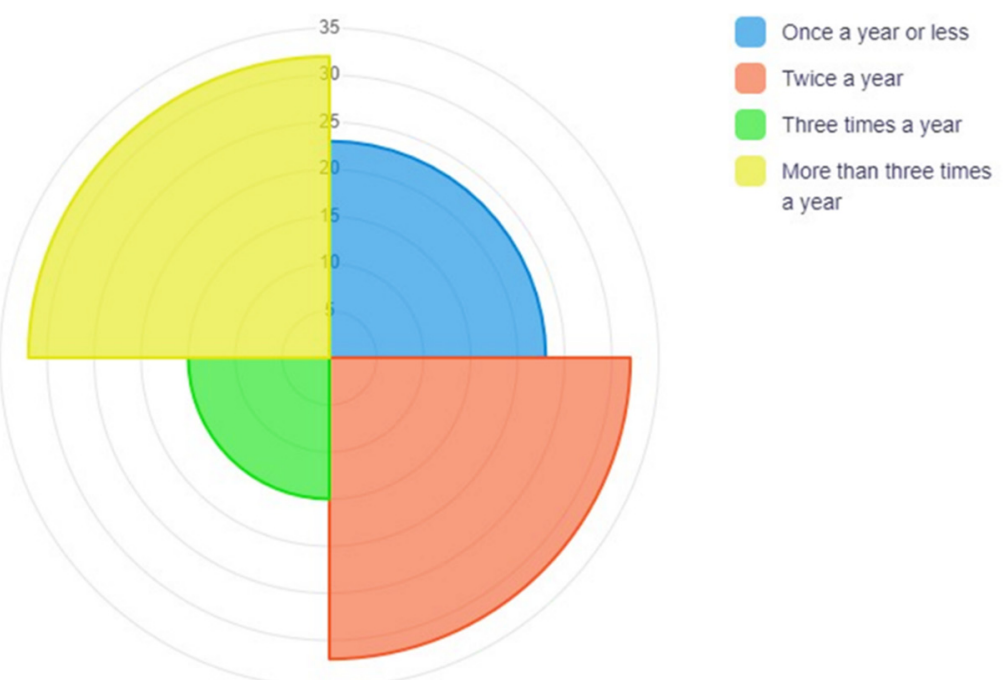

Figure 7. Travel frequency.

Although none of the participants presented a no-travel background, the COVID-19 pandemic seemed to have influenced their future travel plans, since $17.71 \%$ considered not 
traveling again in the next few years or only doing so in unavoidable circumstances (also $17.71 \%$ ) (See Figure 8).

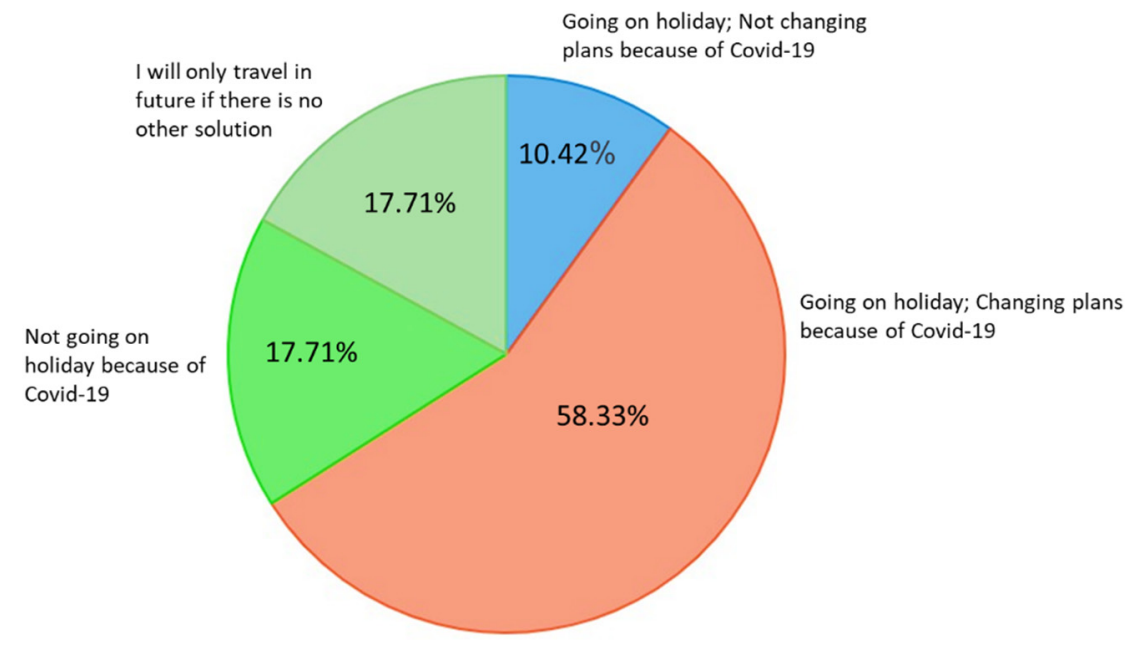

Figure 8. Future traveling intention.

Almost $47 \%$ of the participants made these trips to visit relatives and friends. This number will likely drop after COVID-19, with only $21 \%$ of the participants stating that they would be motivated to visit relatives and friends on future trips.

Regarding the level of importance participants gave to the destination health measures implemented after COVID-19 (see Figure 9), 76\% of the respondents considered the health safety standards of the destination to be important or very important.

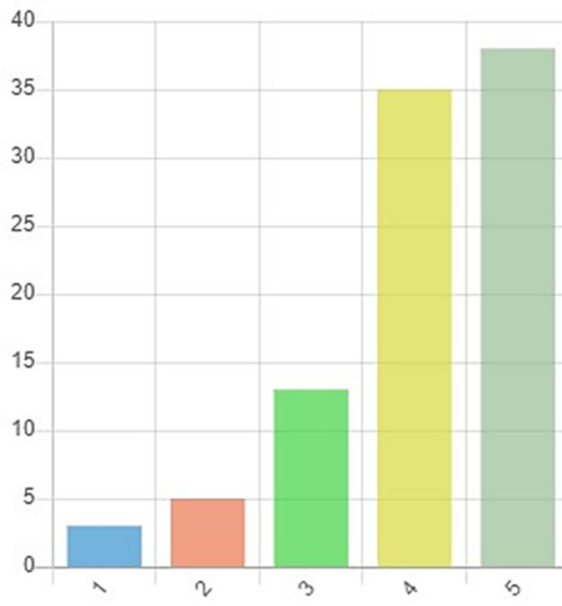

Not Important

Slightly Important

Moderately Important

Important

Very Important

Figure 9. Importance of health measures.

Furthermore, we asked the respondents if they valued the existence of a label indicating safe and clean practices (e.g., the Safe and Clean accreditation label in Portugal) in the destination or service used (accommodation, attraction); $54.17 \%$ considered this to be very important.

We also sought to determine their opinions on the price and cancellation policies, with $45.83 \%$ considering lenient cancellation policies as being very important. Similarly, $44.79 \%$ greatly valued the possibility of making travel modifications without penalties. The participants were asked whether they came across untrustworthy information when looking at online information about their last trip (see Figure 10); $48.96 \%$ of the participants recalled coming across misinterpretations of reality, while $34.38 \%$ received confusing information. 


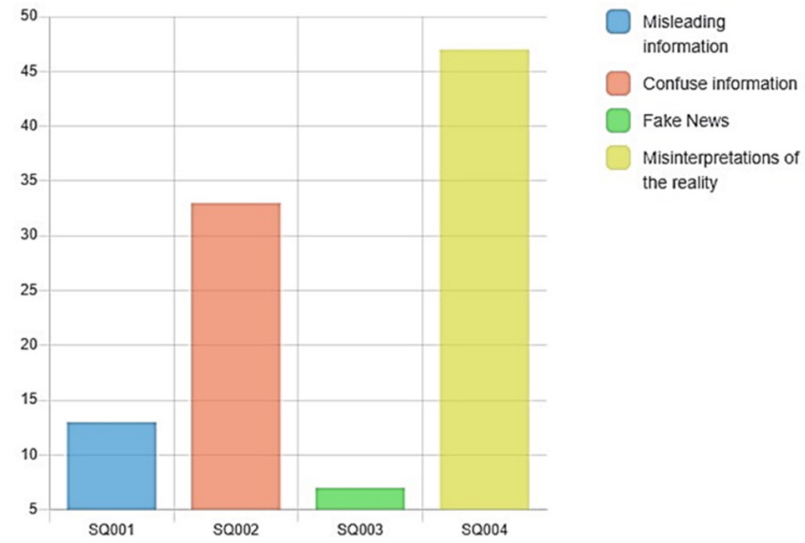

Figure 10. Less trustworthy information online.

\section{Results}

PLS-SEM analysis was conducted to assess the direct and indirect influence of technology and social media on travel sentiment and the direct impact of travel intentions, concerns, and trip planning on travel sentiment.

The initial variables were reduced to a smaller dataset by conducting exploratory factor analysis. Technological usage, travel intent, and travel concerns have three factors each; trip planning has four, and social media usage and travel sentiment have two (See Table 1).

Table 1. The outcomes of exploratory factor analysis.

\begin{tabular}{|c|c|c|}
\hline Dimension & Factors & Variables \\
\hline \multirow{3}{*}{$\begin{array}{l}\text { Technology Usage } \\
\quad(\mathrm{KMO}-0.924)\end{array}$} & Automation technologies & TCH1 \\
\hline & Robots and V/A reality & $\mathrm{TCH} 2$ \\
\hline & Online booking & TCH3 \\
\hline \multirow{2}{*}{$\begin{array}{l}\text { Social Media Usage } \\
\quad(\mathrm{KMO}-0.885)\end{array}$} & Searching & SM1 \\
\hline & Sharing and Socializing & SM2 \\
\hline \multirow{3}{*}{$\begin{array}{l}\text { Travel Intentions } \\
(\mathrm{KMO}-0.915)\end{array}$} & Present intentions & TR1 \\
\hline & Past intentions & TR3 \\
\hline & Future intentions & TR5 \\
\hline \multirow{3}{*}{$\begin{array}{l}\text { Travel Concerns } \\
(\mathrm{KMO}-0.926)\end{array}$} & Travel & TC1 \\
\hline & Health and Safety & TC2 \\
\hline & Financial & TC3 \\
\hline \multirow{4}{*}{$\begin{array}{l}\text { Trip Planning } \\
(\mathrm{KMO}-0.935)\end{array}$} & $\begin{array}{c}\text { Destination characteristics (e.g., distance, location, } \\
\text { sustainability strategy) }\end{array}$ & $\mathrm{TP} 1$ \\
\hline & Timeline and frequency & TP2 \\
\hline & Health destination conditions & TP3 \\
\hline & Reservation policies & $\mathrm{TP} 4$ \\
\hline \multirow{2}{*}{$\begin{array}{l}\text { Travel Sentiment } \\
(\mathrm{KMO}-0.807)\end{array}$} & Sentiment for domestic travel & TRS1 \\
\hline & Sentiment for international travel & TRS2 \\
\hline
\end{tabular}

According to Hajli [71], the research models' path coefficients are significant at 0.05 . Hair et al. [69] pointed out that loadings above 0.708 explain more than $50 \%$ of the indicators' variance, showing an acceptable level of item reliability. In the present model, two items related to travel intention and technological usage were below this reference value but above the 0.5 limit. Therefore, they remain in the final model, considering their theoretical 
relevance. The SRMR (0.08) is within the limit, so it can be assumed that the model has a good fit [71].

In addition, travel concerns factors have a negative value, implying that all positive impacts found in this construct need to be considered to minimize travel concerns (see Figure 11).

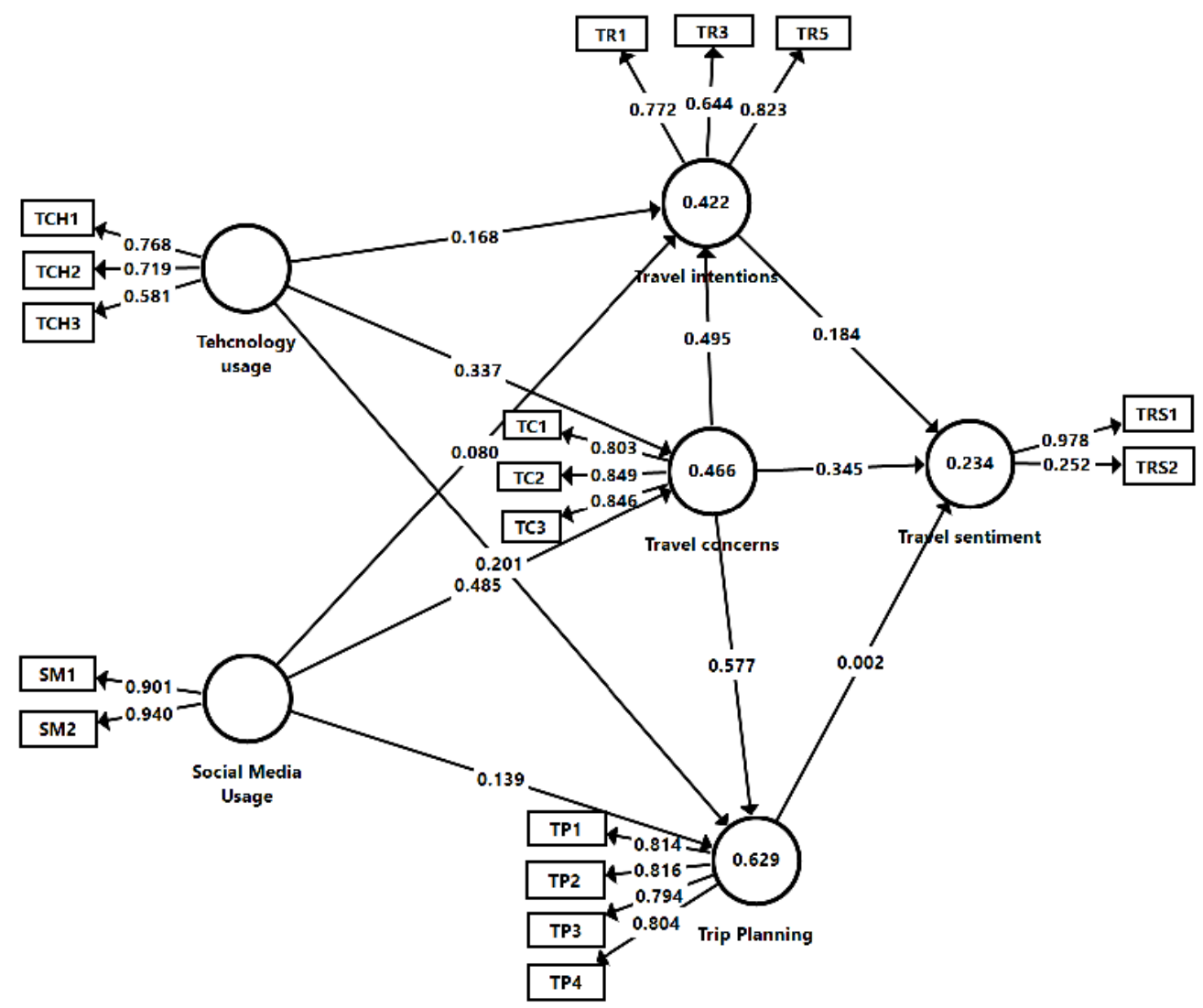

Figure 11. Model estimation.

The coefficient paths indicate that social media usage has a residual positive impact on travel intentions (0.08) and trip planning (0.139). Social media presents a more significant and positive impact on travel concerns (0.485). However, its indirect effect through travel concerns is more significant. The dimension most impacted by technology usage was travel concerns (0.337). However, technology usage also positively impacts travel intentions (0.168) and trip planning. Travel concern is the construct that mainly influences travel sentiment (0.345), trip planning (0.577), and travel intentions (0.495). Contrary to expectations, trip planning has a residual effect on travel sentiment (0.002).

At this point, travel sentiment seems to be primarily anchored in domestic travel (0.978), since the value found for international traveling is reduced.

Thus, the model was once more estimated, only considering the travel sentiment related to domestic traveling. In this model, three new variables that were left out of the original model due to their more minor explanation power, but that were quite present in the literature after COVID-19, were integrated: the healthcare system's past influence (TR4), the healthcare system's present influence (TR5) modification [20], and experience with technology usage (TCH4) $[37,48]$. Once more, to assess the validity and reliability of each construct, the test recommendations of Hair et al. [69] were followed: Cronbach's alpha ( $>0.7)$, the rho_A $(>0.7)$ and the composite reliability $(>0.7)$. Table 2 shows that the values exceeded the required thresholds. 
Table 2. Construct validity and reliability.

\begin{tabular}{cccc}
\hline Construct & Cronbach's Alpha & rho_A & Composite Reliability \\
\hline Social Media Usage & 0.82 & 0.86 & 0.92 \\
Technology Usage & 0.71 & 0.75 & 0.82 \\
Travel Concerns & 0.78 & 0.78 & 0.87 \\
Travel Intentions & 0.73 & 0.76 & 0.82 \\
Travel Sentiment & 1.00 & 1.00 & 1.00 \\
Trip Planning & 0.82 & 0.82 & 0.88 \\
\hline
\end{tabular}

To assess the model's discriminant validity, the Fornell and Larcker criterion was used (See Table 3). Once more, the discriminant validity can be accepted for this measurement model and supports the discriminant validity between the constructs.

Table 3. Discriminant validity: Fornell and Larcker criterion (Smartpls outputs).

\begin{tabular}{ccccccc}
\hline Construct & SMU & TU & TC & TI & TS & TP \\
\hline Social Media Usage (SMU) & 0.92 & & & & & \\
\hline Technology Usage (TU) & 0.55 & 0.73 & & & & \\
\hline Travel Concerns (TC) & 0.61 & 0.74 & 0.83 & & & \\
\hline Travel Intentions (TI) & 0.54 & 0.66 & 0.76 & 0.70 & & \\
\hline Travel Sentiment (TS) & 0.41 & 0.37 & 0.45 & 0.50 & 1.00 & \\
\hline Trip Planning (TP) & 0.56 & 0.80 & 0.76 & 0.72 & 0.38 & 0.81 \\
\hline
\end{tabular}

The second model was estimated after establishing that the construct measures were valid and reliable (See Figure 12). As a criterion of model fit measure, the standardized root means square residual was observed. Since the SRMR was 0.08 , which is within the limit, it can be assumed that the model has a good fit [71].

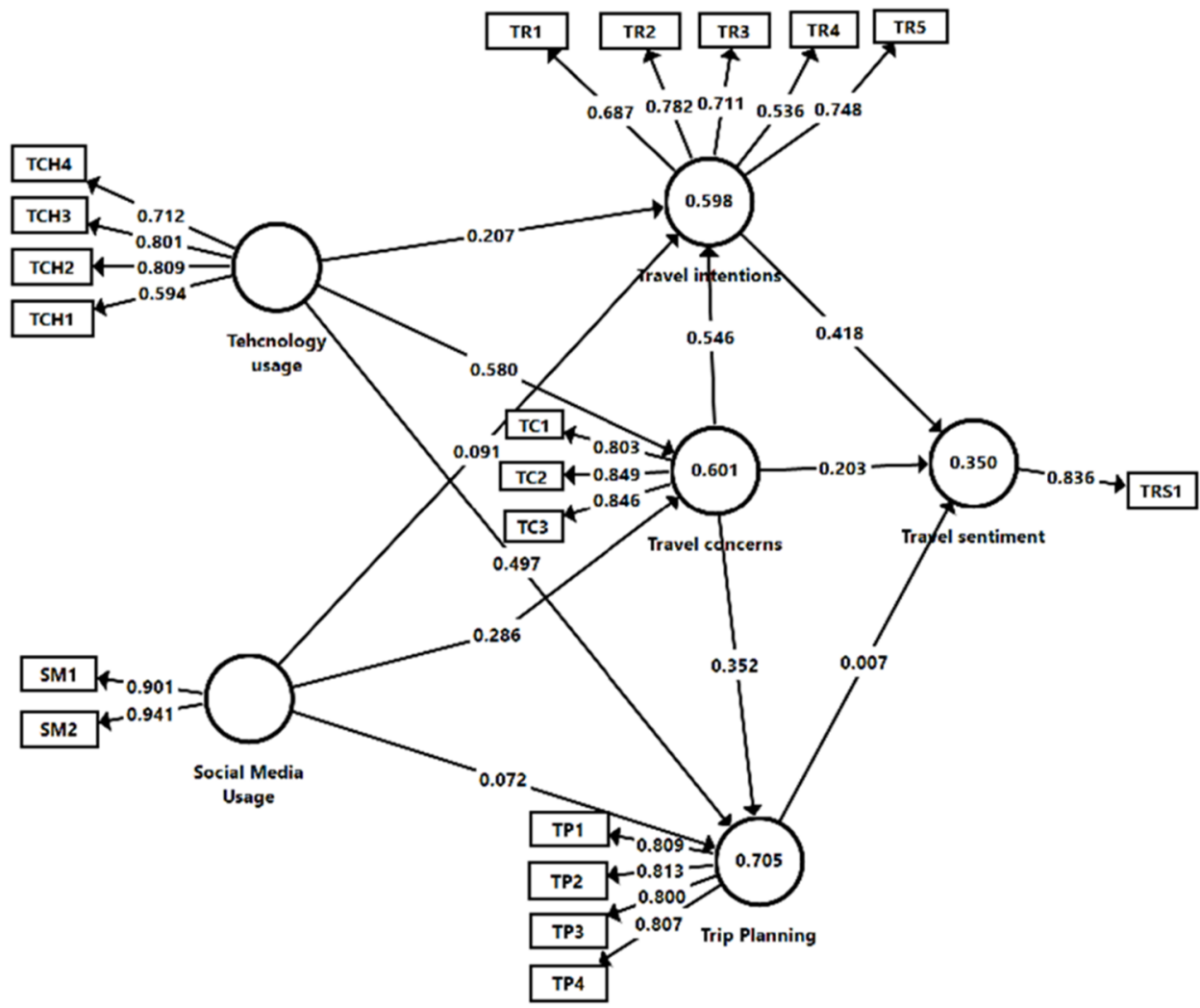

Figure 12. Second model estimation. 
The Smartpls bootstrapping process results show that travel intention, travel concerns, and trip planning are positively and significantly associated with travel sentiment.

The effect of travel intention (0.418) is higher than both travel concerns $(0.203)$ and trip planning effect (0.007). Thus, in this second model, the influence of travel intention on travel sentiment increases, and the negative influence of travel concerns are reduced.

The use of technologies presents a positive impact on travel concerns (0.580), trip planning (0.497), and travel intention (0.207), highlighting the positive spillovers of technology usage pre-trip.

It was also found that social media usage can positively influence travel intention and trip planning. However, the influence is almost residual. Social media was found above all to influence traveling concerns (0.286).

\section{Discussion}

Restarting the tourism and hospitality business depends on many variables, some related to promoting the willingness to travel $[18,32]$. Digital communication, especially over social media platforms, is considered determinant to trigger this willingness since people have started to use social media for social engagement and as an information source [6,7]. However, minimum attention has been paid to the direct effect of social media on reducing traveling concerns related to health and safety [20,27], although several studies have considered the health and safety, travel, and financial risks as inhibitors of traveling intention $[10,27,30,32]$.

The COVID-19 pandemic has also changed the way people and businesses explore technology in their daily routines $[8,34]$ and its impact on the tourism and hospitality ecosystem $[46,63]$. Automation technologies, robots, and virtual and augmented reality have become standard components of tourism experiences [38,39,72] and are perceived as minimizing the risks [38]. On the other hand, online booking enhances expression, since people in their homes have started dreaming and planning upcoming travels [66].

Studies have provided helpful information regarding behavioral travel changes in pos-COVID-19, based on established theories: travel risk perception; travel motivations; travelers' behavior; trip planning; and travel intention. Nonetheless, they seem to fail to show an outcome that firms can understand and use to support their decisions. In contrast, our study attempt is based on established theories to validate the measurement used by firms, coined as travel sentiment. Furthermore, we identified the dynamics underlying the model constructs, using a partial least squares structural equation model estimation.

The path analysis revealed that technology usage positively correlates with trip planning and an ever-stronger association with travel concerns and intention. This outcome supports the idea that tourists are aware of the benefits of adopting technology, especially those related to health and safety procedures $[36,38,66]$.

This study considered social media usage, based on the activity list posited by Hysa et al. [64]. The path analysis indicated that, above all, social media usage influences travel concerns, which can explain the fact that social media during pandemics became a space for virtual communities' anchors regarding health issues $[4,6,20]$.

The travel sentiment construct, also known as a willingness to travel, used in this research supports the most extensive empirical and theoretical evidence that it is a combination of various sub-constructs with different explanations of power, varying between domestic and international traveling. As previously mentioned, the travel sentiment integrates three dimensions already considered in the literature but not always assessed together: travel intentions, trip planning, and travel concerns [32-34]. The findings of this study allow us to validate the relationship proxy used by consultancy firms, supporting it with the extensive literature. Additionally, the current study explains the underlying conditions found in the literature that consultancy firms did not consider and that might affect the effectiveness of digital communication. 


\section{Conclusions}

Recent studies have examined a wide range of behavioral changes, due to consumers' adaptation to the pandemic scenario [8,16]. COVID-19 has transformed tourist behavior and preferences toward destinations that offer familiar, less crowded, trustworthy, and low-risk conditions $[3,16]$. Therefore, proactive communication will be necessary to reignite tourism activity and enhance travel willingness.

As Grewal et al. [11] make clear, the content needs to be carefully composed to promote awareness and motivate consumers to restart their travels. Thus, revealing the factors that may affect travel sentiment or willingness to travel is critical to developing engaging digital communication.

The present time is a unique opportunity to rethink and refresh future destination, tourism, and hospitality offers that are tailored to the new tourist profiles. Yu et al. [20] noted that tourist risk perceptions, impacts on travel, public health, and media coverage are present in most of the literature in a dispersed manner. This study reviewed these different concepts and composed six constructs (social media usage, technology usage, travel intentions, travel concerns, trip planning, and travel sentiment) in an attempt to combine them to reveal the influences of travel sentiment. Moreover, this research attempts to bridge academia and consultants, establishing common ground: travel sentiment equals willingness to travel. Thus, firms can easily find support for their decision in research outcomes from academia or consultancy firms, knowing that they covered the same baselines.

This study advanced the literature on travelers' behavior, highlighting the components that mostly affect travel sentiment. The findings indicate that not all the dimensions constituting travel sentiment equally affect travel sentiment. Thus, digital communication should emphasize the most highly valued dimensions. They also show that travel concerns directly stimulate travel sentiment, suggesting that all actions taken to reduce travel concerns may positively influence tourists' willingness to travel. Moreover, social media usage was found to have a significant mediating role in reducing travel concerns. The technology used also has a similar effect. The automation technologies and robots are considered most relevant, followed by the artificial intelligent response system.

Reports have highlighted that travelers will "place greater importance on pre-trip planning and rely on online forums for swift and transparent access to information" [55]. Yet, curiously, trip planning plays a minor role in the model. Consequently, sustainable destination efforts do not present themselves as critical factors of trip planning. Perhaps, if data were collected after the vaccination process is complete, this dimension would have more impact.

The first model that was estimated pointed to the fact that the type of destinationnational versus international-might affect the travel sentiment. Since this conclusion is aligned with other research outcomes [19], a second model was estimated that only considered national travel intentions. The results reinforced the idea that for domestic travelers, trip planning is not as essential as travel intention and concerns to promote the willingness to travel or, in other words, to promote a positive travel sentiment.

Additionally, the survey outcome allows us to perceive the importance given by tourists-to-be to the destination's health measures, as implemented after COVID-19, ranging from government policy measures to "safe and clean" accreditation systems or cancellation policies. All of these point to the valorization of measures that minimize the different interpersonal and intrapersonal risks, in line with the results of Khan et al. [26].

The urgency to restart tourism activity may lead to a less strategic communication process. Nonetheless, as this study's findings reveal, to promote a positive travel sentiment, it is necessary to implement a set of actions related to healthcare and safety and communicate this effectively to reduce travel concerns. In addition, social media was found to be a source of information used by tourists, with apparent effects on the overall travel sentiment. Therefore, it is advised that DMOs and tourism and hospitality firms develop a set of "safe and clean" procedures and share this via social media so that people become aware of the practices implemented. 
As a pilot study, this work has several limitations related to the constituting dimensions influencing travel sentiment. Considering the ever-evolving COVID-19 pandemic context, the data used may not fully disclose the present status of tourist behavior. Further research should be conducted to confirm the present model and ensure that vaccinations have not altered the relationship between travel constraints and sentiment. Moreover, this research should be undertaken in destinations pursuing sustainable tourism strategies, to reveal whether trip planning that integrates sustainable concerns increases its relevance as a travel sentiment influencer.

Author Contributions: Conceptualization, T.B.-T., S.S., S.A. and F.T.; investigation, T.B.-T., S.S., J.P.C., F.T., L.M.-F. and S.A.; writing, T.B.-T., S.S., J.P.C., F.T., L.M.-F. and S.A. All authors have read and agreed to the published version of the manuscript.

Funding: We gratefully acknowledge financial support from FCT-Fundação para a Ciencia e Tecnologia (Portugal) through research grants UIDB/04521/2020 of the Advance/CSG-ISEG; and UIDB/00685/2020 of the Centre of Applied Economics Studies of the Atlantic-University. This study is a contribution to the research project 'SMART TOURISM AZORES' (Ref. ACORES-01-0145-FEDER000017) funded through FEDER (85\%) and regional funds (15\%) via 'Programa Operacional Açores 2020 '. We also greatly appreciated and thanked the editor and the reviewers for their complimentary comments and suggestions.

Institutional Review Board Statement: Not applicable.

Informed Consent Statement: Informed consent was obtained from all subjects involved in the study.

Data Availability Statement: Not applicable.

Conflicts of Interest: The authors declare no conflict of interest.

\section{References}

1. Becker, E. How Hard Will the Coronavirus Hit the Travel Industry. National Geographic 2020. Available online: https://www. nationalgeographic.com/travel/2020/04/how-coronavirus-is-impacting-the-travel-industry/ (accessed on 13 July 2021).

2. Jones, P.; Comfort, D. The role of resilience in research and planning in the tourism industry. Athens J. Tour. 2020, 7, 1-16. [CrossRef]

3. Sharma, G.D.; Thomas, A.; Paul, J. Reviving tourism industry post-COVID-19: A resilience-based framework. Tour. Manag. Perspect. 2021, 37, 100786. [CrossRef]

4. Machado, A.F.; Sousa, B.B.; Rocha, A.M.A.; de Abreu, Z.H.L. Education Excellence and Innovation Management: A 2025 Vision to Sustain Economic Development during Global Challenges; Communication Strategies to Combat the Negative Effects of Covid-19 on Tourism; International Business Information Management Association: Sevilla, Spain, 2020; pp. 10997-11005.

5. Hu, F.; Teichert, T.; Deng, S.; Liu, Y.; Zhou, G. Dealing with pandemics: An investigation of the effects of COVID-19 on customers' evaluations of hospitality services. Tour. Manag. 2021, 85, 104320. [CrossRef]

6. Fonseca, J.; Borges-Tiago, T.; Tiago, F.; Silva, S. Virtual Communities in COVID-19 Era: A Citizenship Perspective. In Strategic Innovative Marketing and Tourism in the COVID-19 Era, Proceedings of the 9th ICSIMAT Conference, Online, Greece, 2020; Springer International Publishing: New York, NY, USA, 2021.

7. Arens, E. How COVID-19 Has Changed Social Media Engagement. Available online: https://sproutsocial.com/insights/covid1 9-social-media-changes/\#volume-updates (accessed on 17 July 2020).

8. Sheth, J. Impact of Covid-19 on consumer behavior: Will the old habits return or die? J. Bus. Res. 2020, 117, 280-283. [CrossRef]

9. Theodoridis, P.K.; Kavoura, A.; Theodoridis, P.K.; Kavoura, A. The Impact of COVID-19 on Consumer Behaviour: The Case of Greece. In Strategic Innovative Marketing and Tourism in the COVID-19 Era, Proceedings of the 9th ICSIMAT Conference, Online, Greece, 2020; Springer International Publishing: New York, NY, USA, 2021.

10. Chan, C.-S. Developing a Conceptual Model for the Post-COVID-19 Pandemic Changing Tourism Risk Perception. Int. J. Environ. Res. Public Health 2021, 18, 9824. [CrossRef]

11. Grewal, D.; Herhausen, D.; Ludwig, S.; Ordenes, F.V. The future of digital communication research: Considering dynamics and multimodality. J. Retail. 2021. [CrossRef]

12. Lamb, T.L.; Winter, S.R.; Rice, S.; Ruskin, K.J.; Vaughn, A. Factors that predict passengers willingness to fly during and after the COVID-19 pandemic. J. Air Transp. Manag. 2020, 89, 101897. [CrossRef] [PubMed]

13. Susanto, I.; Kiswantoro, A. Tourism Branding: A Strategy of Regional Tourism Sustainability Post COVID-19 in Yogyakarta. IOP Conf. Ser. Earth Environ. Sci. 2021, 704, 012003.

14. Sigala, M. Tourism and COVID-19: Impacts and implications for advancing and resetting industry and research. J. Bus. Res. 2020, 117, 312-321. [CrossRef] 
15. Abdullah, M.; Dias, C.; Muley, D.; Shahin, M. Exploring the impacts of COVID-19 on travel behavior and mode preferences. Transp. Res. Interdiscip. Perspect. 2020, 8, 100255. [CrossRef] [PubMed]

16. Shamshiripour, A.; Rahimi, E.; Shabanpour, R.; Mohammadian, A.K. How is COVID-19 reshaping activity-travel behavior? Evidence from a comprehensive survey in Chicago. Transp. Res. Interdiscip. Perspect. 2020, 7, 100216. [CrossRef] [PubMed]

17. Miao, L.; Im, J.; Fu, X.; Kim, H.; Zhang, Y.E. Proximal and distal post-COVID travel behavior. Ann. Tour. Res. 2021, 88, 103159. [CrossRef]

18. Gössling, S.; Scott, D.; Hall, C.M. Pandemics, tourism and global change: A rapid assessment of COVID-19. J. Sustain. Tour. 2020, 29, 1-20. [CrossRef]

19. Falahuddin, A.F.; Tergu, C.T.; Brollo, R.; Nanda, R.O. Post COVID-19 Pandemic International Travel: Does Risk Perception and Stress-Level Affect Future Travel Intention. J. Ilmu Sos. Ilmu Polit. 2020, 24, 1-14. [CrossRef]

20. Yu, M.; Li, Z.; Yu, Z.; He, J.; Zhou, J. Communication related health crisis on social media: A case of COVID-19 outbreak. Curr. Issues Tour. 2020, 24, 2699-2705. [CrossRef]

21. Kock, F.; Josiassen, A.; Assaf, A.G. On the origin of tourist behavior. Ann. Tour. Res. 2018, 73, 180-183. [CrossRef]

22. Heitmann, S. Tourist behaviour and tourism motivation. Res. Themes Tour. 2011, 3, 31-44.

23. Iso-Ahola, S.E. Towards a social psychology of recreational travel. Leis. Stud. 1983, 2, 45-56. [CrossRef]

24. Aebli, A.; Volgger, M.; Taplin, R. A two-dimensional approach to travel motivation in the context of the COVID-19 pandemic. Curr. Issues Tour. 2021, 1-16. Available online: https://www.tandfonline.com/doi/full/10.1080/13683500.2021.1906631?casa_token= vuVBzysBpqgAAAAA\%3A8aa6nG_j4mAmh61K2BIy8gbiUkCud167xIbonIU1Q5hulmftFqk4h1jp7v0zU3k9Aeub_fp6bXczJA (accessed on 23 October 2021). [CrossRef]

25. Camilleri, M.A. Tourism Planning and Destination Marketing; Emerald Publishing: Bingley, UK, 2019.

26. Khan, M.J.; Chelliah, S.; Ahmed, S. Intention to visit India among potential travellers: Role of travel motivation, perceived travel risks, and travel constraints. Tour. Hosp. Res. 2019, 19, 351-367. [CrossRef]

27. Godovykh, M.; Pizam, A.; Bahja, F. Antecedents and outcomes of health risk perceptions in tourism, following the COVID-19 pandemic. Tour. Rev. 2021, 76, 737-748. [CrossRef]

28. Shin, H.; Nicolau, J.L.; Kang, J.; Sharma, A.; Lee, H. Travel decision determinants during and after COVID-19: The role of tourist trust, travel constraints, and attitudinal factors. Tour. Manag. 2022, 88, 104428. [CrossRef] [PubMed]

29. Wilson, M.E.; Chen, L.H. Restarting travel in the era of COVID-19: Preparing anew. J. Travel Med. 2020, 27, taaa108. [CrossRef]

30. Sánchez-Cañizares, S.M.; Cabeza-Ramírez, L.J.; Muñoz-Fernández, G.; Fuentes-García, F.J. Impact of the perceived risk from Covid-19 on intention to travel. Curr. Issues Tour. 2021, 24, 970-984. [CrossRef]

31. Kusumaningrum, D.A.; Wachyuni, S.S. The shifting trends in travelling after the COVID 19 pandemic. Int. J. Tour. Hosp. Rev. 2020. Available online: https://www.emerald.com/insight/content/doi/10.1108/JTF-04-2020-0063/full/html?utm_source= rss\&utm_medium=feed\&utm_campaign=rss_journalLatest (accessed on 23 October 2021). [CrossRef]

32. Matiza, T. Post-COVID-19 crisis travel behaviour: Towards mitigating the effects of perceived risk. J. Tour. Futures 2020. [CrossRef]

33. Koo, C.; Joun, Y.; Han, H.; Chung, N. A structural model for destination travel intention as a media exposure Belief-desire-intention model perspective. Int. J. Contemp. Hosp. Manag. 2016, 28, 1338-1360. [CrossRef]

34. Wachyuni, S.S.; Kusumaningrum, D.A. The effect of COVID-19 pandemic: How are the future tourist behavior? J. Educ. Soc. Behav. Sci. 2020, 33, 67-76. [CrossRef]

35. Wang, L.; Kirilenko, A.P. Information and Communication Technologies in Tourism; Do tourists from different countries interpret travel experience with the same feeling? Sentiment analysis of TripAdvisor reviews; Springer Publishing: New York, NY, USA, 2021; pp. 294-301.

36. PAVIĆ, Sandra. The Impact of COVID-19 on Technology in the Hotel Industry. Ph.D. Thesis, RIT, Dubrovnik, Zagreb, Croatia, 2021.

37. Wani, M.; Raghavan, V.; Abraham, D.; Kleist, V. Beyond utilitarian factors: User experience and travel company website successes. Inf. Syst. Front. 2017, 19, 769-785. [CrossRef]

38. Seyitoğlu, F.; Ivanov, S. Service robots as a tool for physical distancing in tourism. Curr. Issues Tour. 2021, 24, 1631-1634. [CrossRef]

39. Çakar, K.; Aykol, Ş. Understanding travellers' reactions to robotic services: A multiple case study approach of robotic hotels. J. Hosp. Tour. Technol. 2020, 12, 155-174. [CrossRef]

40. Pencarelli, T. The digital revolution in the travel and tourism industry. Inf. Technol. Tour. 2020, 22, 455-476. [CrossRef]

41. Stankov, U.; Gretzel, U. Tourism 4.0 technologies and tourist experiences: A human-centered design perspective. Inf. Technol. Tour. 2020, 22, 477-488. [CrossRef]

42. Borges-Tiago, T.; Veríssimo, J.; Tiago, F. Smart tourism: A scientometric review (2008-2020). Eur. J. Tour. Res. 2021, $30,3006$.

43. Cohen, S.A.; Hopkins, D. Autonomous vehicles and the future of urban tourism. Ann. Tour. Res. 2019, 74, 33-42. [CrossRef]

44. Murphy, J.; Gretzel, U.; Pesonen, J. Marketing robot services in hospitality and tourism: The role of anthropomorphism. J. Travel Tour. Mark. 2019, 36, 784-795. [CrossRef]

45. Werthner, H.; Klein, S. Information Technology and Tourism: A Challenging Ralationship; Springer: Vienna, Austria, 1999.

46. Buhalis, D. Technology in tourism-from information communication technologies to eTourism and smart tourism towards ambient intelligence tourism: A perspective article. Tour. Rev. 2020, 75, 267-272. [CrossRef]

47. Xiang, Z. From digitization to the age of acceleration: On information technology and tourism. Tour. Manag. Perspect. 2018, 25, 147-150. [CrossRef] 
48. Wang, D.; Xiang, Z.; Fesenmaier, D.R. Smartphone use in everyday life and travel. J. Travel Res. 2016, 55, 52-63. [CrossRef]

49. Wang, D.; Park, S.; Fesenmaier, D.R. The role of smartphones in mediating the touristic experience. J. Travel Res. 2012, 51, 371-387. [CrossRef]

50. Law, R.; Chan, I.C.C.; Wang, L. A comprehensive review of mobile technology use in hospitality and tourism. J. Hosp. Mark. Manag. 2018, 27, 626-648. [CrossRef]

51. Gretzel, U.; Fuchs, M.; Baggio, R.; Hoepken, W.; Law, R.; Neidhardt, J.; Pesonen, J.; Zanker, M.; Xiang, Z. e-Tourism beyond COVID-19: A call for transformative research. Inf. Technol. Tour. 2020, 22, 187-203. [CrossRef]

52. Wagler, A.; Hanus, M.D. Comparing virtual reality tourism to real-life experience: Effects of presence and engagement on attitude and enjoyment. Commun. Res. Rep. 2018, 35, 456-464. [CrossRef]

53. Kwok, A.O.; Koh, S.G. COVID-19 and extended reality (X.R.). Curr. Issues Tour. 2021, 24, 1935-1940. [CrossRef]

54. Huertas, A.; Gonzalo, J. The Role of Augmented Reality in Destination Branding. Tour. Hosp. Manag. 2020, 26, 419-436. [CrossRef]

55. Wyman, O. To Recovery \& Beyond: The Future of Travel \& Tourism in the Wake of COVID-19; WTTC: London, UK, 2020.

56. Ivanova, M.; Ivanov, I.K.; Ivanov, S. Travel behaviour after the pandemic: The case of Bulgaria. Anatolia 2021, 32, 1-11. [CrossRef]

57. Tiago, T.; Couto, J.P.; Tiago, F.; Faria, S.D. From comments to hashtags strategies: Enhancing cruise communication in Facebook and Twitter. Tourismos 2017, 12, 19-47.

58. Tiago, T.; Veríssimo, J. Digital marketing and social media: Why bother? Bus. Horiz. 2014, 57, 703-708. [CrossRef]

59. Borges-Tiago, M.T.; Arruda, C.; Tiago, F.; Rita, P. Differences between TripAdvisor and Booking.com in branding co-creation. J. Bus. Res. 2021, 123, 380-388. [CrossRef]

60. Fotis, J.; Buhalis, D.; Rossides, N. Social Media Use and Impact during the Holiday Travel Planning Process; Springer: Vienna, Austria, 2012.

61. Hennig-Thurau, T.; Hofacker, C.F.; Bloching, B. Marketing the pinball way: Understanding how social media change the generation of value for consumers and companies. J. Interact. Mark. 2013, 27, 237-241. [CrossRef]

62. Kavoura, A.; Stavrianeas, A. The importance of social media on holiday visitors' choices-The case of Athens, Greece. EuroMed J. Bus. 2015, 10, 360-374. [CrossRef]

63. Buhalis, D.; Sinarta, Y. Real-time co-creation and nowness service: Lessons from tourism and hospitality. J. Travel Tour. Mark. 2019, 36, 563-582. [CrossRef]

64. Hysa, B.; Karasek, A.; Zdonek, I. Social media usage by different generations as a tool for sustainable tourism marketing in society 5.0 idea. Sustainability 2021, 13, 1018. [CrossRef]

65. Sotiriadis, M.D. Sharing tourism experiences in social media: A literature review and a set of suggested business strategies. Int. J. Contemp. Hosp. Manag. 2017, 29, 179-225. [CrossRef]

66. MacSween, S.; Canziani, B. Travel booking intentions and information searching during COVID-19. Int. Hosp. Rev. 2021. ahead-of-print. [CrossRef]

67. Tussyadiah, I.P.; Park, S. When guests trust hosts for their words: Host description and trust in sharing economy. Tour. Manag. 2018, 67, 261-272. [CrossRef]

68. Marton, Z.; Ernszt, I. Omnipresent Social Media: Is Travelling Imaginable without Smart Devices? Manag. Glob. Transit. Int. Res. J. 2020, 18, 301-322.

69. Hair, J.F.; Risher, J.J.; Sarstedt, M.; Ringle, C.M. When to use and how to report the results of PLS-SEM. Eur. Bus. Rev. 2019, 33, 2-24. [CrossRef]

70. Ali, F.; Rasoolimanesh, S.M.; Sarstedt, M.; Ringle, C.M.; Ryu, K. An assessment of the use of partial least squares structural equation modeling (PLS-SEM) in hospitality research. Int. J. Contemp. Hosp. Manag. 2018, 30, 514-538. [CrossRef]

71. Hajli, M.N. A study of the impact of social media on consumers. Int. J. Mark. Res. 2014, 56, 387-404. [CrossRef]

72. Tussyadiah, I.P.; Park, S. Information and Communication Technologies in Tourism; Consumer evaluation of hotel service robots; Springer: Cham, Switzerland, 2018; pp. 308-320. 